\title{
In memory of Giovanni
} Arrighi

A colleague for some and a teacher and mentor for others associated with New Perspectives on Turkey, Professor Giovanni Arrighi of the Johns Hopkins Universiry passed away on 18 June 2009, after a yearlong battle with cancer.

Born on 7 July 1937 in Italy, Giovanni Arrighi earned the title of "dottore in economia" at the Universitá Bocconi and started his academic career in Zimbabwe (then Rhodesia) and Tanzania during the 1960s, where he turned away from neoclassical economics and towards political economy while writing his seminal articles on capitalist development in southern Africa. After a number of years in Italy, Giovanni in 1979 joined the Sociology Department at Binghamton University (then called State University of New York, Binghamton), which was becoming a bastion of world-systems analysis and historical sociology. ${ }^{1}$ There, Giovanni taught several generations of $\mathrm{PhD}$ students until he moved to the Sociology Department at Johns Hopkins in 1998. Having been at both institurions, as a graduate student in the former and a post-doctoral fellow in the latter, I can count more than a dozen graduate students from Turkey who took his courses ar Binghamton and Johns Hopkins; several of us, including myself, consider him an intellectual mentor.

Giovanni never conducted research or wrote on Turkey, ${ }^{2}$ but his comparative-historical scholarship was a source of intellectual inspiration

1 For a very insightful account of Arrighi's intellectual journey and his life's work, see his interview with David Harvey in the New Left Review, Giovanni Arrighi, "The Winding Paths of Capital," New Left Review, no. 56 (2009).

2 The only exception I can think of is his paper "Fascism to Democratic Socialism: Logic and Limits of a Transition," in which he compares the rise of authoritarian regimes in Turkey, Greece, Italy, Portugal and Spain. See, Giovanni Arrighi, ed. Semiperipheral Development: The Politics of Southern Europe in the Twentieth Century (Beverly Hills: Sage,1985). In this edited book, he collaborated, among other col. leagues associated with Binghamton, with Çaglar Keyder, one of the founding and long-time editors of New Perspectives on Turkey. 
for many graduate students from (semi)peripheral countries, including Turkey. ${ }^{3}$ At Binghamton, Giovanni and the other two towering figures of world-systems analysis, Immanuel Wallerstein and the late Terence $\mathrm{K}$. Hopkins, introduced us to the theoretical giants behind this perspective. They shared a common, though critical, interest in the works of Karl Marx, Fernand Braudel, Karl Polanyi and Joseph Schumpeter; yet, each of them had different emphases. Schumpeter perhaps had a unique place in Arrighi's intellectual pedigree, and Braudel's work was crucial for him, too, especially in The Long Twentieth Century, ${ }^{4}$ where he explained successive historical phases of financial expansion by putting Braudel's insights about capitalism under theoretical scrutiny. But it was not so much Giovanni's historical analysis of hegemonic transitions in The Long Twentieth Century that attracted Turkish students: at Binghamton, almost none of us were interested in studying anything orher than Turkey, and so the analytical level of hegemonies did not have much operational value for designing dissertation research. Later at Johns Hopkins, while Giovanni was busy writing his book on the rise of China in the capitalist world-economy, ${ }^{5}$ he and his wife and partner in scholarship Beverly Silver continued to attract Turkish students.

It was not just the subject-matter of Giovanni's writing, but rather the breadth of his intellectual vision, the sharpness of his political insights, and the theoretical depth of his work (along with those of Wallerstein and Hopkins) that inspired many graduate students. From his much earlier critical work on proletarianization in southern Africa ${ }^{6}$ to his "geometry" of imperialism; ${ }^{7}$ from his collaborative work on anti-systemic movements ${ }^{8}$ to his joint work with Beverly Silver on such issues as labor movements ${ }^{9}$

3 Although he did not write on Turkey, his two major monographs, along with some of his collaborative works from his time in Binghamton, have been translated into Turkish. For instance, see Arrighi, Uzun Yirminci Yüzyıl. Para, Cü̧̧ ve Çă̆ımızın Kökenleri, trans. Recep Boztemur (Ankara: İmge Kitabevi, 2000); Adam Smith Pekin'de. 21. Yüzyilin Soykütü̆ü, trans. ibrahim Yıldız (istanbul: Yordam Kitap, 2009). Most recently, his interview with David Harvey was published as a book in Turkish. See Arrighi, Sermayenin Dolambaçlı Yolları, trans. Osman Akınhay (Istanbul: Agora Kitaplı̆̆ı, 2009).

4 Giovanni Arrighi, The Long Twentieth Century: Money, Power and the Origins of Our Times (London: Verso, 1994).

5 Arrighi, Adam Smith in Beijing. Lineages of the Twenty-First Century (London: Verso, 2007).

6 E.g., Arrighi, "Labour Supplies in Historical Perspective: A Study of the Proletarianization of the African Peasantry in Rhodesia," in Essays on the Political Economy of Africa, eds. Ciovanni Arrighi and John Saul (New York: Monthly Review Press, 1973); Arrighi, "The Political Economy of Rhodesia," New Left Review, no. 1 (?966).

7 Giovanni Arrighi, The Geometry of Imperialism, Revised Edition (London: Verso, 1983).

8 Giovanni Arrighi, Terence K. Hopkins, and Immanuel Wallerstein, Antisystemic Movements (London: Verso, 1989).

9 E.g., Giovanni Arrighi and Beverly Silver, "Labor Movements and Capital Migration: The Us and Europe in World-Historical Perspective," in Labor in the Capitalist World-Economy, ed. Charles Bergquist (Beverly Hills: Sage, 1984). 
and the persistence of global inequalities; ${ }^{10}$ from his emphasis on the significance of business enterprises and financialization processes under different hegemonic powers ${ }^{11}$ to his fascination with the rise of East Asia in the world-economy ${ }^{12}$-students could find theoretical and methodological openings for their own research in Giovanni's opus even when their projects were conceived at the national rather than the global level.

There was more to Giovanni as a reacher than just his scholarly perspective. At both universities, his seminars-distinguished by his animated style of lecturing and his gift for global and historical comparisons over the span of several hours and his gift for global and historical comparisons-were popular among students from various departments. In a dissertation seminar, I once witnessed him draw analytical parallels between nomads in the steppes of Central Asia in the early modern period with modern traders around the Black Sea, all of which he simultaneously charted on the blackboard. He also had a great sense of humor; he once said in the classroom: "I know only two types of culture; one, Braudel's material culture, and the other, culture as in a throat culture." Another significant aspect of Giovanni's charm was his friendliness towards graduate students and his protective attitude towards his advisees (some of us called him "the Don" at Binghamton).

His students and colleagues will greatly miss Giovanni's warm personality and his scholarly advice; but his intellectual legacy and political vision will remain with us for a long time to come in these trying times of global economic and political turbulence.

\section{Deniz Yükseker}

Koç University

\section{References}

Arrighi, Giovanni. Adam Smith in Beijing. Lineages of the Twenty-First Century. London: Verso, 2007.

-. Adam Smith Pekin'de. 21. Yüzyilin Soykütügü. Translated by Ibrahim Yıldız. Istanbul: Yordam Kitap, 2009.

-. The Geometry of Imperialism. Revised Edition. London: Verso, 1983.

—. "Labour Supplies in Historical Perspective: A Study of the Proletarianization of the African Peasantry in Rhodesia." In Essays on the Political Economy of Africa, edited by Giovanni Arrighi and John Saul.

10 Giovanni Arrighi, Beverly Silver, and Benjamin D. Brewer, "Industrial Convergence and the Persistence of the North-South Divide," Studies in Comparative International Development 38, no. 1 (2003).

11 Arrighi, Long Twentieth Century; Giovanni Arrighi and Beverly Silver, Chaos and Covernance in the Modern World System (Minneapolis: University of Minnesota Press, 1999).

12 Arrighi, Adam Smith in Beijing; Ciovanni Arrighi, Takeshi Hamashita, and Mark Selden, eds., The Resurgence of East Asia. 500, 150 and 50 Year Perspectives (London and New York: Routledge, 2003). 


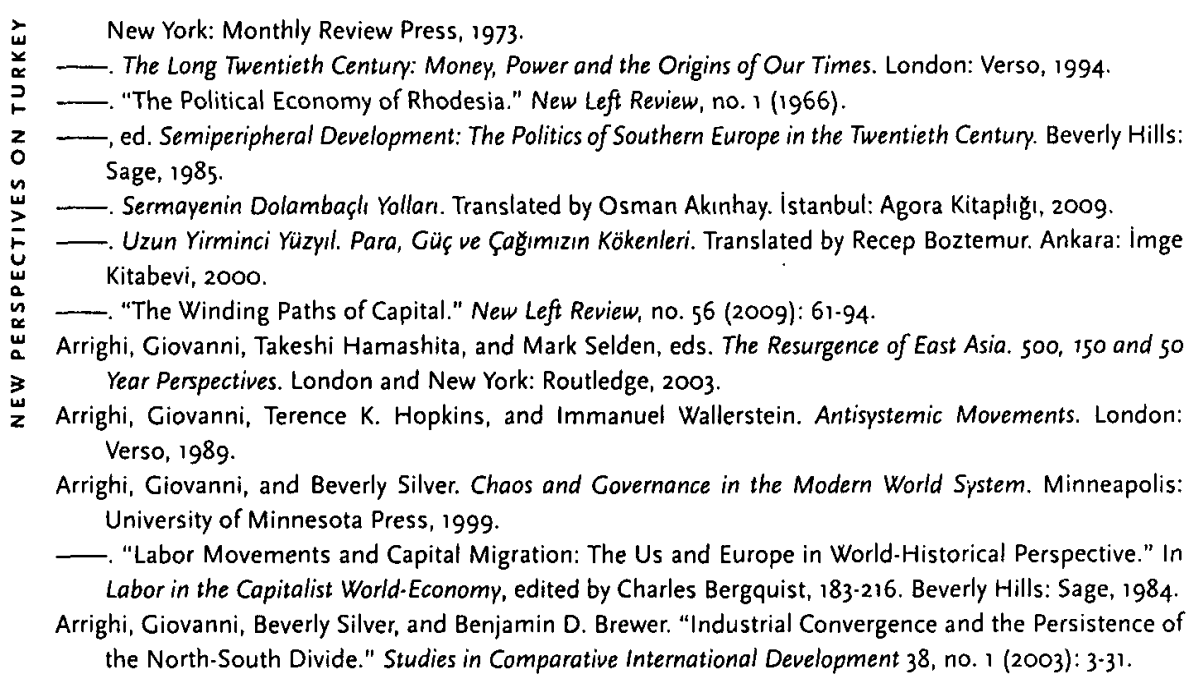

